\title{
SISTEM PAKAR DIAGNOSIS PENYAKIT TANAMAN CABAI DENGAN METODE FORWARD CHAINING DAN DEMPSTER SHAFER
}

\author{
(Expert System With Forward Chaining and Dempster Shafer Method for Diagnosis \\ of Chili Plants Diseases)
}

\author{
Mega Laely ${ }^{*}$ I Gede Pasek Suta Wijaya, Arik Aranta \\ Program Studi Teknik Informatika, Fakultas Teknik, Universitas Mataram \\ JI. Majapahit 62, Mataram, Lombok NTB, INDONESIA \\ Email:megalaily295@gmail.com, [gpsutawijaya, arikaranta]@unram.ac.id
}

\begin{abstract}
Chili plant (Capsicum Annum) is one of the horticultural commodities whose fruit has a high nutritional value, especially vitamin $A$ and $C$ content. Nationally, the productivity and harvested area of chilies are the highest compared to other horticultural commodities. One of the problems in chili plants is the attack of chili disease which can reduce the quality and quantity of chili production. This study aims to develop an expert system for diagnosis of chili plant diseases based on the knowledge of three experts using seven chili disease data and 32 symptom data. This study uses four testing techniques, namely black box testing with results that are functional in accordance with the design, testing with "theoretical calculations" in two case examples producing accurate calculation results with system calculation results, the system accuracy tester is $96.67 \%$ in the First Expert who tested 30 cases, the Mean Opinion Score (MOS) test results in a MOS score of 4.35 for Informatics Engineering students, 4.00 for Agriculture students, 4.68 for Agricultural Instructors, and 4.54 for farmers which is categorized into good system.
\end{abstract}

Keywords: expert system, chili, chili disease, Forward Chaining, Dempster Shafer

*Penulis Korespondensi

\section{Pendahuluan}

Tanaman cabai (Capsicum annum) termasuk dalam komoditi hortikultura yang buahnya memilki kandungan gizi cukup tinggi terutama kandungan vitamin A dan C. Penggunaan cabai yang cukup luas baik dalam bentuk segar maupun olahan menyebabkan komoditi ini memiliki nilai ekonomi tinggi. Nilai ekonomi yang tinggi menjadi alasan petani untuk terus membudidayakan tanaman cabai sebagai mata pencarian dalam memenuhi kebutuhan hidup [1].

Jenis cabai yang digunakan pada penelitian ini adalah cabai rawit. Menurut laporan Badan Pusat Statistika (BPS) tahun 2018, produktivitas cabai rawit di Indonesia dari tahun 2013-2018 selalu mengalami kenaikan, dengan hasil produksi pada tahun 2013 mencapai 721 ribu ton dan luas panen 125.1 ribu $\mathrm{Ha}$ meingkat menjadi 1,34 juta ton dan luas panen 172.8 ribu Ha pada tahun 2018[2]. Nusa Tenggara Barat (NTB) adalah provinsi dengan hasil produksi cabai rawit terbesar kedua di Indonesia[2]. Menurut laporan BPS (NTB) tahun 2018 hasil produksi cabai rawit pada tahun 2018 mencapai 211 ribu ton dengan luas panen 8.2 ribu Ha dan meningkat sebesar 34.16 persen dibandingkan produksi tahun 2017 yang hanya mencapai 152 ribu ton dengan luas panen $8.0 \mathrm{Ha}$ [3].

Luas panen cabai rawit menurut data terakhir 2018 berada pada peringkat pertama dalam komoditi hortikultura dengan luas 7,7 ton/hektar [2]. Angka tersebut belum mencapai potensi hasilnya yang berkisar antara 12-20 ton/hektar [4]. Perkembangan produksi cabai dapat dipengaruhi oleh beberapa kendala yaitu, kendala dari segi agronomi dan pemasaran yang dapat menurunkan produksi dan pendapatan petani . Contoh dari segi agronomi yaitu adanya Organisme Pengganggu Tanaman (OPT) pada tanaman cabai [1].

Organisme pengganggu tanaman yang dapat menyerang tanaman cabai mulai dari tahap persemaian hingga panen. Salah satu contoh yaitu patogen yang merupakan cikal bakal dari penyakit pada tanaman cabai [4]. Terbatasnya jumlah penyuluh yang menyebabkan kegiatan penyuluhan terkait budidaya tanaman cabai dan penanggulan penyakit tanaman cabai terhadap petani yang mengakibatkan 
minimnya pengetahuan petani terhadap budidaya dan penanggulan penyakit tanaman cabai [5].

Sistem pakar adalah salah aplikasi kecerdasan buatan menampung pengetahuan manusia dalam sistem komputer sehingga dapat memecahkan permaslahan seperti layaknya pakar yang dapat digunakan untuk memperoleh informasi tanpa terbatas ruang dan waktu [6]. Saat ini sistem pakar telah banyak diterapkan dalam berbagai bidang salah satunya pada bidang pertanian seperti pada penyakit tanaman cabai.

Sistem pakar pada penelitian ini menggunakan metode Forward Chaining, Forward Chaining adalah teknik penelusuran berdasarkan data-data yang ada untuk mendapatkan kesimpulan [7]. Dempster Shafer merupakan metode penalaran non monotonis yang digunakan untuk mencari ketidakpastian karena terdapat perubahan fakta baru yang dapat merubah rule yang ada, sehingga metode ini memungkinkan orang awam dapat memperoleh informasi dengan cepat tanpa harus berjumpa dengan pakar [8]. Dalam penelitian sistem pakar untuk mendiagnosis gangguan kepribadian menghasilkan tingkat akurasi untuk metode Dempster Shafer lebih tinggi yaitu sebesar $90 \%$ sedangkan Certainty Factor sebesar 85\% [9].

Berdasarkan uraian di atas, pada penelitian ini akan dibangun sistem pakar untuk mendiagnosis penyakit tanaman cabai dengan metode Forward Chaining dan Dempster Shafer yang berbasis web sehingga pengguna dapat mengakses sistem dimana saja dan kapan saja menggunakan handphone atau Personal Compter (PC) tanpa perlu me-install aplikasi dan Pakar dapat mengelola basis pengetahuan jika dikeperluan.

\section{TINJAUAN PUSTAKa}

\subsection{Tinjauan Pustaka}

Rendahnya produksi cabai disebabkan berbagai kendala seperti serangan Organisme pengganggu tanaman yang dapat menyerang tanaman cabai mulai dari tahap persemaian hingga panen. Salah satu contoh yaitu patogen yang merupakan cikal bakal dari penyakit pada tanaman cabai [4]. Patogen dapat berupa makhluk hidup (animate pathogen), tetapi juga sesuatu yang tidak hidup (inanimate pathogen) seperti virus, hara, air atau penyebab lainnya [4]. Maka sistem pakar diagnosis penyakit tanaman cabai adalah solusi bagi petani untuk dapat melakukan diagnosis terhadap penyakit yang tanaman cabai.

Penelitian terkait dengan sistem pakar untuk mendiagnosis penyakit tanaman cabai telah banyak dilakukan dengan beberapa metode, yaitu penelitian menggunakan metode certainty factor untuk mendiagnosis penyakit tanaman cabai, terdapat enam data penyakit dan 22 data gejala dengan tingkat akurasi sebesar $76 \%$, pada penelitian ini perlu ditambahkan data penyakit dan gejala [10]. Penelitian menggunakan metode Naive Bayes untuk mendiagnosis penyakit cabai terdapat 15 data hama dan penyakit tanaman cabau serta 41 data dengan tingkat akurasi sebesar $90.47 \%$ [11]. Penerapan metode Bayes pada penelitian untuk mendiagnosis hama dan penyakit tanaman cabai, terdapat 11 data hama dan penyakit, serta 34 data gejala dengan tingkat kepercayaan dari hasil pengujian adalah 0.32 , sedangkan jumlah pakarnya adalah hanya satu Pakar [12].

Penelitian terdahulu tentang sistem pakar dalam penerapan metode Forward Chaining dan Dempster Shafer yaitu, penelitian menggunakan metode Forward Chaining dalam mendiagnosis penyakit Telinga Hidung Tenggorokan (THT), data yang digunakan sebanyak 10 data penyakit telinga, sembilan data penyakit hidung dan sembilan data penyakit tenggorokan serta 57 data gejala dengan tingkat akurasi sebesar 100\% [7]. Penelitian dalam menerapkan metode Forward Chaining untuk diagnosis dini penyakit tuberkulosis, data yang digunakan sebanyak tiga penyakit tuberkulosis dan 26 gejala dengan tingkat akurasi sebesar 93,333\% [13]. Penelitian menggunakan Forward Chaining dan Dempster Shafer dalam mendiagnosis penyakit kelamin pada pria, data yang digunakan sebanyak lima data penyakit kelamin pada pria dan 18 data gejala, dengan tingkat akurasi sebesar 94,2\% [14]. Penelitian dalam menerapkan metode Forward Chaining dan Dempster Shafer untuk mendiagnosis penyakit ikan koi, dengan tingkat akurasi sebesar $95 \%$ pada 20 kasus uji [15].

Penelitian terdahulu tentang sistem pakar menggunakan metode Dempster Shafer yang telah berhasil mendiagnosis beberapa objek penelitian dengan tingkat akurasi yang tinggi. Penelitian untuk mendiagnosis penyakit tanaman padi, terdapat tujuh jenis data penyakit dan 22 data gejala dengan tingkat akurasi sebesar 90\% [16]. Penelitian tentang diagnosis penyakit tanaman kedelai, terdapat lima jenis data penyakit dengan 16 data gejala dengan tingkat akurasi sistem sebesar 92\% [17]. Penelitian tentang diagnosis penyakit tanaman karet, terdapat 8 data penyakit dan 27 data gejala, tingkat akurasi sebesar $100 \%$ [18]. Penelitian tentang diagnosis penyakit tanaman semangka, terdapat sembilan data penyakit dan 35 data gejala dengan tingkat akurasi sebesar $86 \%$ [19]. 
Penelitian tentang diagnosis penyakit pada kucing terdiri dari sembilan penyakit kucing dan 25 gejala dengan tingkat akurasi sebesar 94,59\% [20].

Penelitian terdahulu tentang analisa perbandingan metode Dempster Shafer dengan beberapa metode lainya. Penelitian tentang analisa perbandingan metode Certainty Factor dengan metode Dempster Shafer dalam mendiagnosis penyakit kelinci, menghasilkan tingkat akurasi untuk metode Certainty Factor lebih rendah yaitu sebesar $80 \%$ sedangkan metode Dempster Shafer sebesar 85\% [21]. Penelitian tentang analisa perbandingan metode Bayesaian Network dengan Dempster Shafer dalam mendiagnosis penyakit sapi, menghasilkan tingkat akurasi metode Bayesaian Network lebih rendah yaitu sebesar sebesar 75,3\% sedangkan Dempster Shafer sebesar 87,2\% [22]. Penelitian tentang analisa perbandingan Dempster Shafer dengan Certainty Factor dalam mendiagnosis gangguan kepribadian, menghasilkan tingkat akurasi untuk metode Dempster Shafer lebih tinggi yaitu sebesar 90\% sedangkan Certainty Factor sebesar $85 \%$ [9].

Berdasarkan uraian tinjauan pustaka di atas, maka akan dikembangkan sebuah sistem pakar yang dapat mendiagnosis penyakit tanaman cabai dengan menerapkan metode Forward Chaining dalam proses penalaran untuk mendapatkan kesimpulan berdasarkan gejala-gejala yang dimasukan dan metode Dempster Shafer untuk memperoleh nilai perhitungan berdasarkan nilai kepercayaan masing-masing gejala.

\subsection{Forward Chaining}

Metode Forward Chaining adalah teknik penelusuran ke depan berdasarkan data-data yang ada untuk mendapatkan kesimpulan. Metode ini cocok bekerja pad permasalahan yang dimulai dengan informasi data-data awal dan ingin dicapai penyelesaian akhir, karena seluruh proses akan dikerjakan secara berurutan maju [7].

\subsection{Dempster Shafer}

Dempster Shafer Theory of Evidence, merupakan suatu metode ketidakpastian yang digunakan untuk memberikan nilai keprcayaan dari suatu fakta yang ada. Teori Dempster Shafer adalah representasi, kombinasi dan propagasi ketidakpastian di mana teori ini memiliki beberapa karakteristik yang secara intuitif sesuai cara berpikir seorang Pakar, namun dengan dasar matematika yang kuat [23].

Dempster shafer pada umumnya terdiri dari interval [Belief, Plausibility]. Belief merupakan tingkat kepercayaan atau kepastian terhadap suatu evidence untuk menghitung nilai proporsisi. Plausibility adalah tingkat ketidakpercayaan atau ketidakpastian terhadap suatu evidence. Rentang interval [Belief, Plausibility] pada metode dempster shafer yaitu dari 0 sampai 1. Plausibility ( $P / s)$ akan menurunkan tingkat kepercayaan dari suatu evidence. Fungsi Belief diformulasikan seperti pada persamaan (1) dan fungsi Plausibility diformulasikan seperti pada persamaan (2) [8].

$\operatorname{Bel}(X)=\sum_{Y \subseteq X} m 1(X)$

$\operatorname{Pls}(X)=1-\operatorname{Bel}(X)$

Keterangan:

$\begin{array}{lll}\mathrm{X} & : & \begin{array}{l}\text { Penyakit yang mengalami gejala } 1 \\ \mathrm{Y}\end{array} \\ \operatorname{Bel}(\mathrm{X}) & : & \begin{array}{l}\text { Penyakit yang mengalami gejala } 2 \\ \text { kelief }(\mathrm{X}), \text { artinya nilai kepercayaan atau }\end{array} \\ \mathrm{Pls}(\mathrm{X}) & : \quad \begin{array}{l}\text { Plausibility }(\mathrm{X}), \text { artinya nilai ketidakpercayaan } \\ \text { atau ketidakpastian penyakit } \mathrm{X} \text { yang mengalami } \\ \text { gejala } 1\end{array} \\ \mathrm{~m} 1(\mathrm{X}) \quad \begin{array}{l}\text { Mass function atau tingkat kepastian dari suatu } \\ \text { evidence }(\mathrm{X})\end{array}\end{array}$

Pada metode Dempster Shafer environment merupakan semesta pembicaraan dari sekumpulan hipotesis yang dinotasikan dengan simbol $\Theta$.

$(\Theta)=\{\theta 1, \theta 2, \ldots \theta N\}$

\section{Keterangan:}

$\theta 1 \ldots \theta n=$ elemen atau unsur bagian dari evirontment

Dalam teori Dempster Shafer tingkat kepercayaan dari suatu evidence disebut Mass function (m) yang diformulasikan pada persamaan (4) [8].

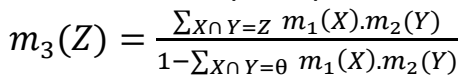

Keterangan:

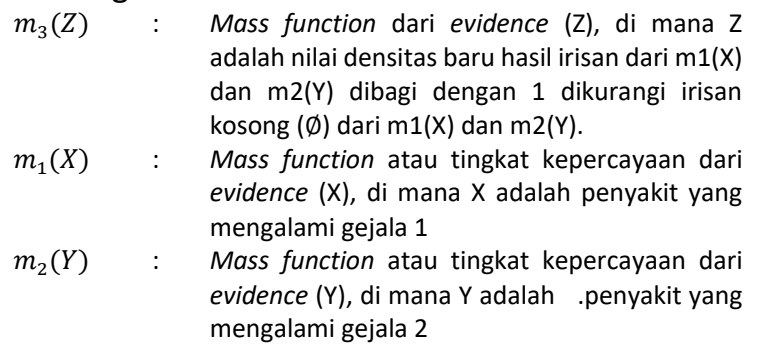

\section{Metode Penelitian}

\subsection{Proses Penelitian}

Proses penelitian sistem pakar diagnosis tanaman cabai dengan metode Forward Chaining dan Dempster Shafer dimulai dari tahap studi literatur sampai tahap penarikan kesimpulan.

\subsubsection{Studi Literatur}

Pada proses penelitian ini studi literatur dilakukan guna mendapatkan garis besar yang dapat digunakan sebagai referensi dalam menyelesaikan permasalahan dan sebagai acuan untuk mengembangkan sistem yang 
akan dibangun. Proses ini dilakukan dengan cara mempelajari dan menelaah buku-buku, literatur dan jurnal-jurnal penelitian yang berhubungan dengan permasalahan terkait sistem pakar, penyakit cabai, metode Forward Chaining dan Dempster Shafer.

\subsubsection{Pengumpulan Data}

Proses pengumpulan data dilakukan dengan cara wawancara pada pakar. Pakar utama sebagai sumber data gejala, penyakit cabai, nilai kepercayaan gejala terhadap suatu penyakit dan saran cara penanganan adalah Bapak Jaswandi,SP. yang merupakan seorang Pengamat Organisme Pengganggu Tanaman (POPT) di UPT Pertanian Kecamatan Labuapi, Kabupaten Lombok Barat. Pakar lain yang membantu memberikan nilai kepercayaan, yaitu Prof. Ir. M. Taufik Fauzi, M.Sc., Ph.D. yang merupakan profesor pada bidang hama dan penyakit tanaman di Fakultas Pertanian Universitas Mataram dan Bapak Awaludin merupakan seorang yang memiliki pengalaman di bidang Organisme Pengganggu Tanaman (OPT) di UPT Pertanian Kecamatan Labuapi, Kabupaten Lombok Barat sejak 2008.

\subsubsection{Perancangan Sistem}

Proses perancangan sistem terdiri dari tahap perancangan arsitektur sistem pakar diagnosis dapat dilihat pada Gambar 1.

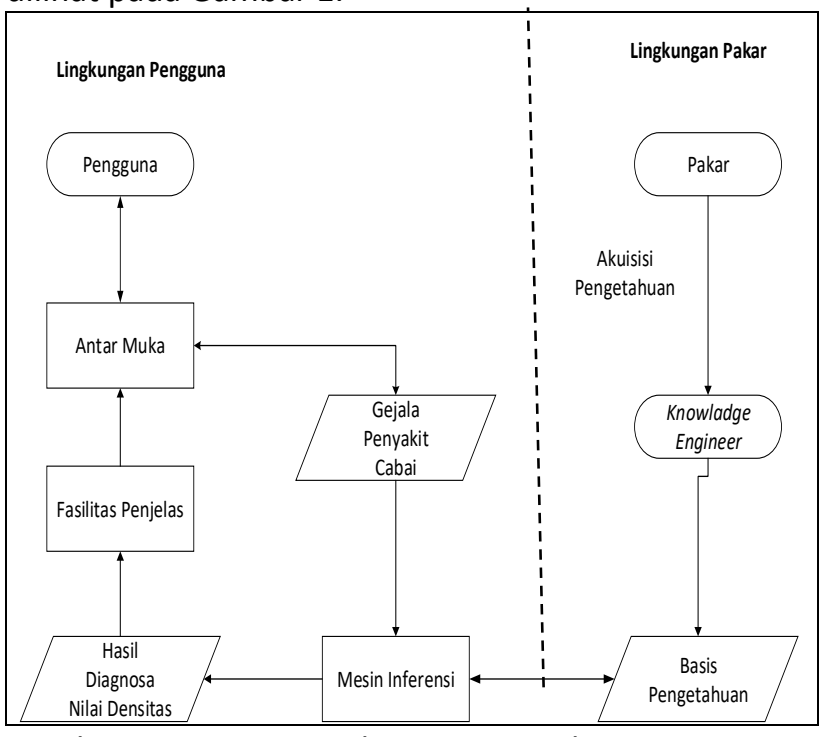

Gambar 1. Desain arsitektur sistem pakar

Akuisisi Pengetahuan merupakan pengumpulan

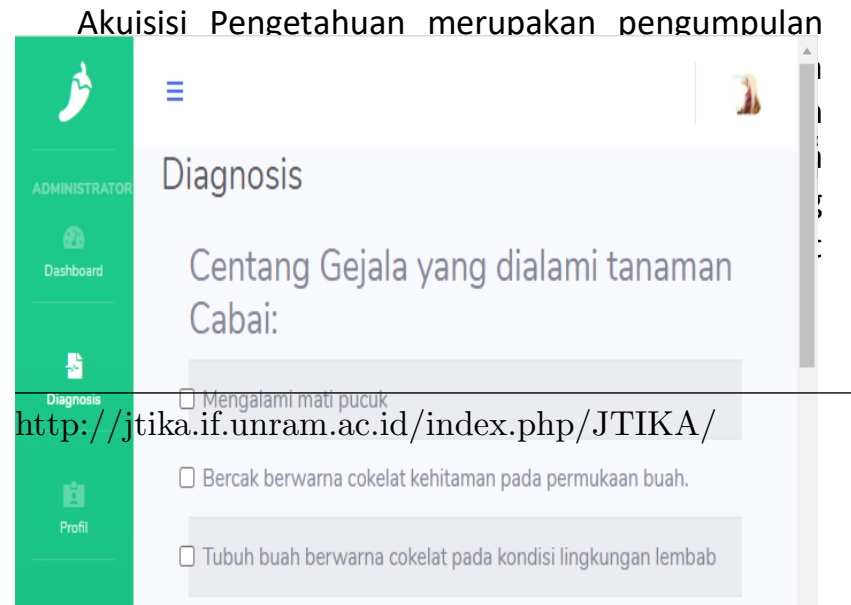

\subsubsection{Implementasi}

Implementasi meliputi implementasi database dan implementasi sistem pakar. Database yang dibuat bernama tapeca yang terdiri dari lima tabel yaitu tabel pengguna, penyakit, gejala, bobot dan riwayat. Struktur tabel-tabel pada database tapeca dapat dilihat pada Gambar 2.

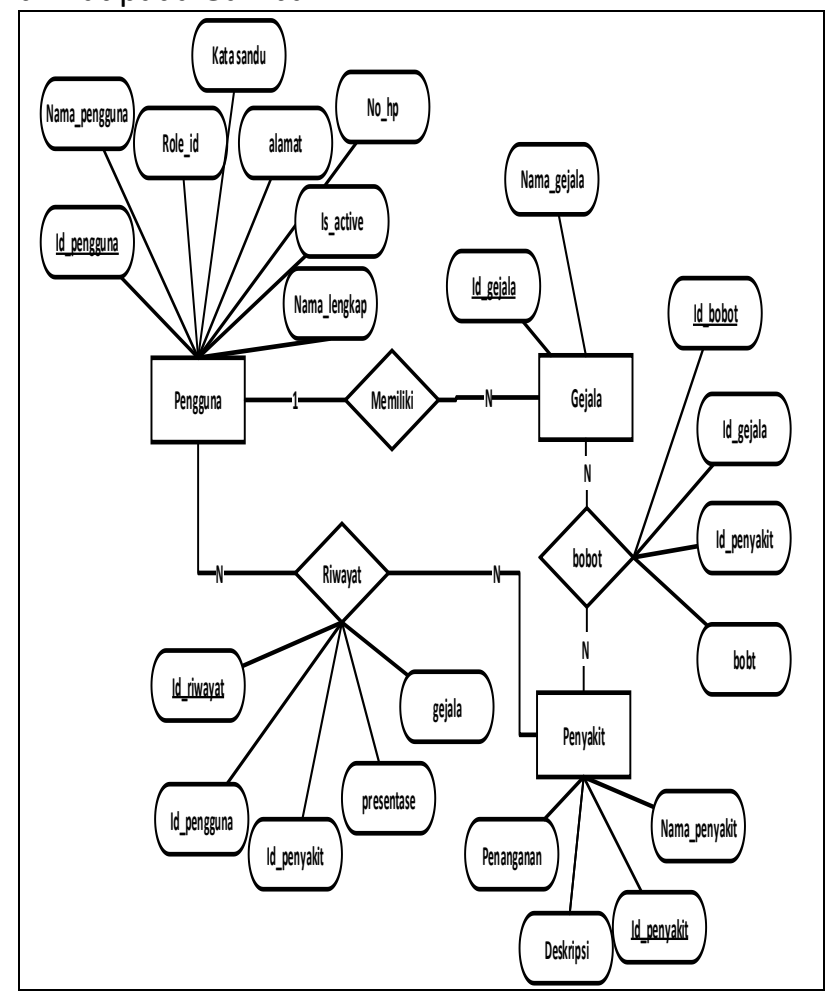

Gambar 2. ERD sistem pakar penyakit tanaman cabai

Database tapeca terdiri dari lima tabel yaitu tabel pengguna, penyakit, gejala, bobot dan riwayat. Tabel pengguna berfungsi untuk menyimpan data pengguna, pada tabel ini terdapat atribut nama pengguna dan kata sandi yang diperlukan untuk login ke sistem oleh petani dan admin sesuai dengan rol_id yang dimiliki. Tabel gejala digunakan untuk menyimpan nama-nama gejala penyakit cabai, tabel bobot yang digunakan untuk menyimpan data relasi tabel gejala dan tabel penyakit serta menyimpan nila belief dari suat gejala. Tabel penyakit digunakan untuk menyimpan data penyakit tanaman cabai. Tabel riwayat untuk menyimpan data riwayat diagnosis petani. Implementasi dari sistem pakar yang telah dibangun seperti pada Gambar 3 dan Gambar 4. 
Gambar 3. Halaman diagnosis

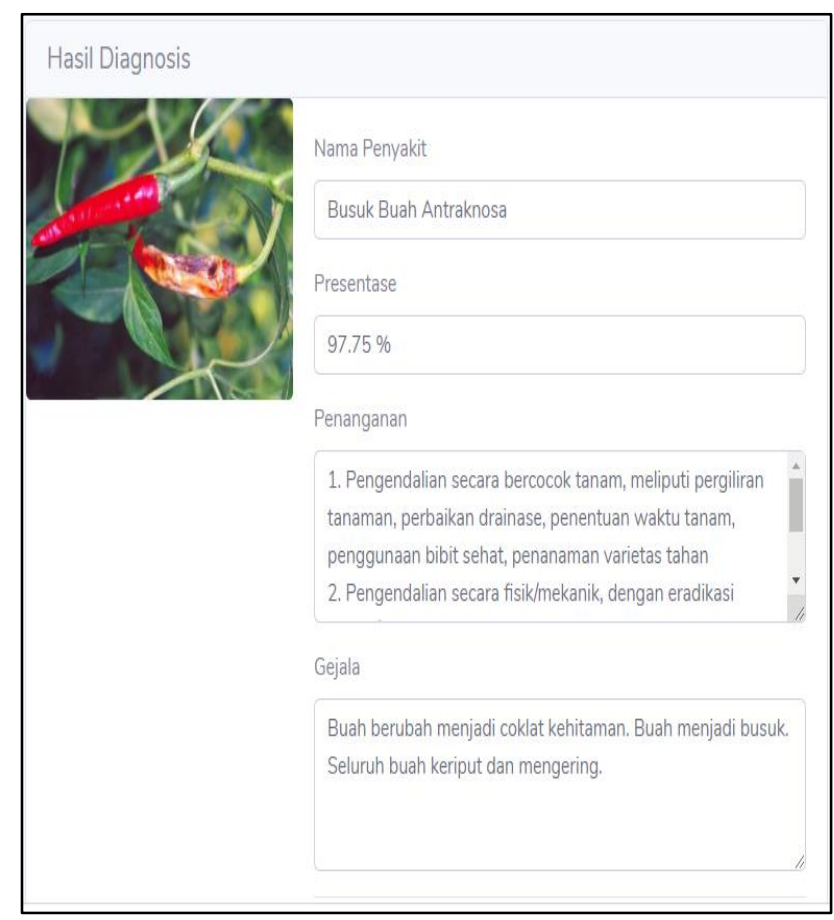

Gambar 4. Halaman hasil diagnosis

\subsubsection{Pengujian Sistem}

Pengujian sistem bertujuan untuk mengetahui tingkat kelayakan sistem, kesesuaian hasil persentase sistem dan seberapa akurat hasil yang diberikan. Pengujian sistem dilakukan dengan 4 teknik pengujian sistem yaitu pengujian black box, pengujian dengan perhitungan teoritis, pengujian Akurasi dan pengujian Mean Opinion Score (MOS).

\section{HASIL DAN PEMBAHASAN}

\subsection{Pengujian Black Box}

Pengujian black box dilakuan untuk menguji fungsionalitas sistem pakar diagnosis penyakit tanaman cabai yang telah dibangun. Pengujian ini dilakukan kepada lima mahasiswa Teknik Informatika
Universitas Mataram. Tabel I merupakan hasil pengujian black box.

taBel I. Hasil Pengujian Black Box

\begin{tabular}{|l|l|}
\hline \multicolumn{1}{|c|}{ Fungsi } & Hasil \\
\hline Fungsi form pendaftaran akun & Valid \\
\hline Fungsi form login pengguna & Valid \\
\hline Fungsi laman petani & Valid \\
\hline Fungsi laman admin & Valid \\
\hline
\end{tabular}

Berdasarkan hasil pengujian pada Tabel I, maka dapat disimpulkan bahwa hasil pengujian black box secara fungsionalitas sistem pakar untuk mendiagnosis penyakit pada tanaman cabai telah berjalan sesuai dengan rancangan sistem.

\subsection{Pengujian dengan "Perhitungan Teoritis"}

Pengujian dengan "perhitungan teoritis" dilakukan untuk mengetahui apakah persentase hasil perhitungan manual sesuai dengan persentase hasil perhitungan sistem. Pengujian ini dilakukan pada satu contoh kasus dengan memasukan tiga gejala pada sistem pakar diagnosis penyakit pada tanaman cabai. Perhitungan ini dimisalkan pengguna memasukan gejala sepeti pada Tabel II.

TABEL II. CONTOH KASUS 1.

\begin{tabular}{|l|l|l|}
\hline \multicolumn{1}{|c|}{ Gejala } & \multicolumn{1}{|c|}{ Nama Penyakit } & Belief \\
\hline Bercak kering (G16) & $\begin{array}{l}\text { Bercak daun } \\
\text { serkospora (P4) }\end{array}$ & 0,9 \\
\hline $\begin{array}{l}\text { Bercak berwana } \\
\text { cokelat pada daun } \\
\text { (G15) }\end{array}$ & $\begin{array}{l}\text { Bercak daun } \\
\text { serkospora (P4) }\end{array}$ & 0,9 \\
\cline { 2 - 3 } & $\begin{array}{l}\text { Busuk Daun Fitoptfora } \\
\text { (P5) }\end{array}$ & 0,53 \\
\hline $\begin{array}{l}\text { Bercak dikelilingi } \\
\text { oleh sporangium } \\
\text { yang berwarna putih } \\
\text { (G20) }\end{array}$ & $\begin{array}{l}\text { Busuk Daun } \\
\text { Fitoptfora(P5) }\end{array}$ & 0,58 \\
\hline
\end{tabular}

a. Gejala G15: Bercak kering

Gejala $\mathrm{G} 15$ memiliki nilai $\mathrm{m}\{\mathrm{P} 4\}=0,9$ untuk mendapatkan densitas pada m1 maka akan dilakukan perhitungan sebagai berikut:

$$
\begin{aligned}
& m 1\{P 4\}=0,9=0,9 \\
& m_{1}\{\theta\}=1-0,9=0.1
\end{aligned}
$$

b. Gejala G14: Bercak berwana cokelat pada daun

Gejala G14 memiliki nilai $m\{P 4\}=0,9$ dan $\mathrm{m}\{\mathrm{P} 5\}=0,53$ maka akan dihitung nilai $\mathrm{m} 1$ yaitu:

$$
\begin{aligned}
& m 2\{P 4, P 5\}=\frac{0,9+0,53}{2}=0,715 \\
& m_{2}\{\theta\}=1-0,715=0,285
\end{aligned}
$$


Maka akan untuk mendapatkan nila densitas baru (m3) dengan beberapa kombinasi yang memungkinkan, dapat dilihat pada Tabel III.

TABEL III. ATURAN KOMBINASI M3 KASUS 2

\begin{tabular}{|l|l|l|}
\hline \multirow{2}{*}{$\mathrm{m} 1$} & \multicolumn{2}{|c|}{$\mathrm{m} 2$} \\
\cline { 2 - 3 } & $\mathrm{m}\{\mathrm{P} 4, \mathrm{P} 5\}=0,715$ & $\mathrm{~m} 2 \theta\}=0,285$ \\
\hline $\mathrm{m} 1\{\mathrm{P} 4)=0$, & $\{\mathrm{P} 4\}=0,9 * 0,715=$ & $\{\mathrm{P} 4\}=0,9 * 0,285=$ \\
9 & 0,644 & 0,257 \\
\hline $\mathrm{m}\{\theta\}=0,1$ & $\{\mathrm{P} 4, \mathrm{P} 5\}=0,1^{*}$ & $\{\theta\}=0,1 \quad *$ \\
& $0,715=0,072$ & $0,285=0,029$ \\
\hline
\end{tabular}

Maka:

$$
\begin{aligned}
& m 3\{P 4\}=\frac{0,644+0,257}{1-0}=0,9 \\
& m 3\{P 4, P 5\}=\frac{0,072}{1-0}=0,072 \\
& m 3\{\theta\}=\frac{0,029}{1-0}=0,029
\end{aligned}
$$

c. Gejala G20: Bercak dikelilingi oleh sporangium yang berwarna putih

Dilakukan observasi bercak dikelilingi oleh sporangium yang berwarna putih sebagai gejala dari penyakit cabai dengan nilai $m\{P 5\}=$ 0,58 untuk mendapatkan densitas pada m4 maka akan dilakukan perhitungan sebagai berikut:

$m 4\{P 5\}=0,58=0,58$

$m 4\{\theta\}=1-0,58=0.42$

Maka akan untuk mendapatkan nila densitas baru (m5) dengan beberapa kombinasi yang memungkinkan, dapat dilihat pada Tabel IV.

TABEL IV. ATURAN Kombinasi M5 KASUS 2

\begin{tabular}{|l|l|l|}
\hline \multirow{2}{*}{$\mathrm{m} 3$} & \multicolumn{2}{|c|}{$\mathrm{m} 4$} \\
\cline { 2 - 3 } & $\mathrm{m}\{\mathrm{P} 5\}=0,58$ & $\mathrm{~m}\{\theta\}=0,42$ \\
\hline $\mathrm{m}\{\mathrm{P} 4)=0,9$ & $\{\theta\}=0,9 * 0,58=0,522$ & $\begin{array}{l}\{\mathrm{P} 4\}=0,9 \\
0,42=0,378\end{array}$ \\
& & $\{P 4, P 5\}=$ \\
$\mathrm{m}$ & $\{\mathrm{P} 5\}=0,072^{*} 0,58=0,042$ & $0,0715^{*} 0,42=$ \\
$\{P 4, P 5\}$ & & 0,03 \\
$=0,072$ & & $\{\theta\}=0,0285^{*} 0,42$ \\
\hline $\mathrm{m}\{\theta\}=0,012$ \\
0,029 & $\{\mathrm{P} 5\}=0,029^{*} 0,58=0,0$ \\
\hline
\end{tabular}

Maka:

$$
\begin{gathered}
m 5\{P 4\}=\frac{0,378}{1-0,522}=0,7908 \\
m 5\{P 5\}=\frac{0,042+0,017}{1-0,522}=0,121 \\
m 5\{P 4, P 5\}=\frac{0,03}{1-0,522}=0,063 \\
m 5\{\theta\}=\frac{0,012}{1-0,522}=0,025
\end{gathered}
$$

Dari perhitungan di atas, diperoleh nilai densitas tinggi adalah $m 3\{P 4\}=0,7908$ atau $79.08 \%$ sehingga dapat disimpulkan penyakit yang menyerang tanaman cabai kemungkinan adalah terserang penyakit Bercak Daun Serkospora (P4).

Hasil diagnosis sistem terhadap kasus satu dapat dilihat pada Gambar 7 yaitu tanaman cabai terserang penyakit Bercak Daun Serkospora dengan persentase sebesar $79.08 \%$. Sehingga dapat disimpulkan hasil persentase pengujian sistem sesuai dengan hasil perhitungan manual.

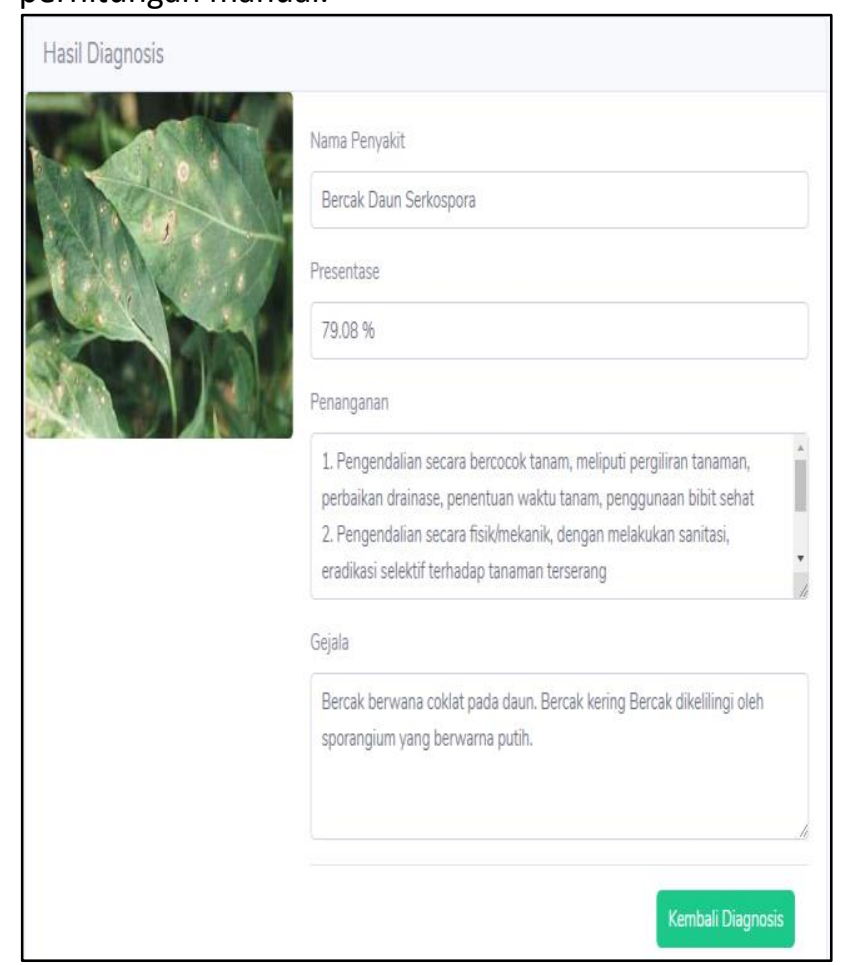

Gambar 7. Hasil diagnosis sistem terhadap kasus 2

\subsection{Pengujian Akurasi Sistem}

Pengujian akurasi dilakukan untuk mengetahui kesesuaian antara hasil diagnosis sistem dan hasil diagnosis pakar. pengujian ini dilakukan oleh tiga pakar pada bidang penyakit tanaman cabai. Pengujian ini menggunakan 30 kasus penyakit tanaman cabai yang bersumber dari data real di lapangan. Pengujian ini terdiri dari dua skenario perhitungan tingkat akurasi, yaitu perhitungan tingkat akurasi berdasarkan nilai akhir kepercayaan tiga pakar dan berdasarkan nilai kepercayaan masing-masing Pakar.

\subsubsection{Akurasi berdasarkan Nilai Akhir Kepercayaan 3 Pakar}

TABEL V. PENGUJIAN AKURASI SISTEM dAN 3 PAKAR

\begin{tabular}{|c|c|c|c|c|}
\hline No & Sistem & $\begin{array}{c}\text { Pakar } \\
1\end{array}$ & $\begin{array}{c}\text { Pakar } \\
2\end{array}$ & $\begin{array}{c}\text { Pakar } \\
3\end{array}$ \\
\hline 1 & $\begin{array}{c}\text { Busuk Buah } \\
\text { Antraknosa } \\
99,99 \%\end{array}$ & $\sqrt{ }$ & $\sqrt{ }$ & $\sqrt{ }$ \\
\hline
\end{tabular}




\begin{tabular}{|c|c|c|c|c|}
\hline 2 & $\begin{array}{c}\text { Busuk Buah } \\
\text { Antraknosa } \\
94,61 \%\end{array}$ & $\sqrt{ }$ & $\sqrt{ }$ & $\sqrt{ }$ \\
\hline 3 & $\begin{array}{c}\text { Layu Fusarium } \\
61,83 \%\end{array}$ & $\sqrt{ }$ & $\sqrt{ }$ & P3 \\
\hline 4 & $\begin{array}{c}\text { Embun Tepung } \\
90.55 \%\end{array}$ & $\sqrt{ }$ & $\sqrt{ }$ & $\sqrt{ }$ \\
\hline 5 & $\begin{array}{c}\text { Bercak Daun } \\
\text { Serkospora } \\
94,7 \%\end{array}$ & $\sqrt{ }$ & $\sqrt{ }$ & $\sqrt{ }$ \\
\hline 6 & $\begin{array}{c}\text { Bercak Daun } \\
\text { Serkospora } \\
96,72 \%\end{array}$ & $\sqrt{ }$ & $\sqrt{ }$ & $\sqrt{ }$ \\
\hline 7 & $\begin{array}{c}\text { Virus Kuning } \\
99,8 \%\end{array}$ & $\sqrt{ }$ & $\sqrt{ }$ & $\sqrt{ }$ \\
\hline 8 & $\begin{array}{c}\text { Layu Bakteri } \\
95,65 \%\end{array}$ & $\sqrt{ }$ & $\sqrt{ }$ & $\sqrt{ }$ \\
\hline 9 & $\begin{array}{c}\text { Embun Tepung } \\
54,04 \%\end{array}$ & $\sqrt{ }$ & $\sqrt{ }$ & $\sqrt{ }$ \\
\hline 10 & $\begin{array}{c}\text { Layu Fusarium } \\
62.82 \%\end{array}$ & $\sqrt{ }$ & $\sqrt{ }$ & P3 \\
\hline 11 & $\begin{array}{c}\text { Busuk Buah } \\
\text { Antraknosa } \\
99,98 \%\end{array}$ & $\sqrt{ }$ & $\sqrt{ }$ & $\sqrt{ }$ \\
\hline 12 & $\begin{array}{l}\text { Layu Bakteri } \\
94,45 \%\end{array}$ & $\sqrt{ }$ & P6 & $\sqrt{ }$ \\
\hline 13 & $\begin{array}{c}\text { Bercak Daun } \\
\text { Serkospora } \\
66,54 \%\end{array}$ & P5 & $\sqrt{ }$ & P5 \\
\hline 14 & $\begin{array}{c}\text { Busuk Daun } \\
\text { Fitophora } 97,97 \%\end{array}$ & $\sqrt{ }$ & $\sqrt{ }$ & $\sqrt{ }$ \\
\hline 15 & $\begin{array}{c}\text { Embun Tepung, } \\
74.2 \%\end{array}$ & $\sqrt{ }$ & $\sqrt{ }$ & $\sqrt{ }$ \\
\hline 16 & $\begin{array}{c}\text { Bercak Daun } \\
\text { Serkospora } \\
98,35 \%\end{array}$ & $\sqrt{ }$ & $\sqrt{ }$ & $\sqrt{ }$ \\
\hline 17 & $\begin{array}{c}\text { Virus Kuning } \\
99.43 \%\end{array}$ & $\sqrt{ }$ & $\sqrt{ }$ & $\sqrt{ }$ \\
\hline 18 & $\begin{array}{c}\text { Busuk Daun } \\
\text { Fitophora } 95,77 \%\end{array}$ & $\sqrt{ }$ & $\sqrt{ }$ & $\sqrt{ }$ \\
\hline 19 & $\begin{array}{c}\text { Busuk Buah } \\
\text { Antraknosa } \\
99,91 \%\end{array}$ & $\sqrt{ }$ & $\sqrt{ }$ & $\sqrt{ }$ \\
\hline 20 & $\begin{array}{c}\text { Layu Fusarium } \\
99,16 \%\end{array}$ & $\sqrt{ }$ & $\sqrt{ }$ & $\sqrt{ }$ \\
\hline 21 & $\begin{array}{c}\text { Layu Bakteri } \\
98,18 \%\end{array}$ & $\sqrt{ }$ & $\sqrt{ }$ & $\sqrt{ }$ \\
\hline 22 & $\begin{array}{c}\text { Busuk Daun } \\
\text { Fitophora } 68.95 \%\end{array}$ & $\sqrt{ }$ & P4 & $\sqrt{ }$ \\
\hline 23 & $\begin{array}{c}\text { Virus Kuning } \\
99,94 \%\end{array}$ & $\sqrt{ }$ & $\sqrt{ }$ & $\sqrt{ }$ \\
\hline
\end{tabular}

\begin{tabular}{|c|c|c|c|c|}
\hline 24 & $\begin{array}{c}\text { Layu Bakteri } \\
98,21 \%\end{array}$ & $\sqrt{ }$ & $\sqrt{ }$ & $\sqrt{ }$ \\
\hline 25 & $\begin{array}{c}\text { Busuk Daun } \\
\text { Fitophora 75,57\% }\end{array}$ & P4 & P4 & $\sqrt{ }$ \\
\hline 26 & $\begin{array}{c}\text { Busuk Buah } \\
\text { Antraknosa } \\
99,99 \%\end{array}$ & $\sqrt{ }$ & $\sqrt{ }$ & $\sqrt{ }$ \\
\hline 27 & $\begin{array}{c}\text { Layu Bakteri } \\
98,08 \%\end{array}$ & $\sqrt{ }$ & $\sqrt{ }$ & $\sqrt{ }$ \\
\hline 28 & $\begin{array}{c}\text { Layu Bakteri } \\
69,94 \%\end{array}$ & $\sqrt{ }$ & $\sqrt{ }$ & P5 \\
\hline 29 & $\begin{array}{c}\text { Bercak Daun } \\
\text { Serkospora } \\
99,27 \%\end{array}$ & $\sqrt{ }$ & $\sqrt{ }$ & $\sqrt{ }$ \\
\hline 30 & $\begin{array}{c}\text { Layu Fusarium } \\
64.72 \%\end{array}$ & $\sqrt{ }$ & $\sqrt{ }$ & $\sqrt{ }$ \\
\hline
\end{tabular}

Keterangan:

$\checkmark \quad:$ Valid

Kode penyakit : Tidak Valid

Tabel $\mathrm{V}$ merupakan perbandingan antara hasil diagnosis Pakar 1 dengan hasil diagnosis sistem, terdapat 28 hasil yang sesuai dan 2 hasil yang tidak sesuai yaitu pada pengujian kasus ke-13 dan ke-25. Maka diperoleh nilai keakuratan Pakar Satu sebesar $\frac{28}{30} \times 100=93,33 \%$.

Hasil diagnosis Pakar Dua dengan hasil diagnosis sistem, terdapat 27 hasil yang sesuai dan 3 hasil yang tidak sesuai yaitu pada pengujian kasus ke-12, ke-22 dan ke-25. Maka diperoleh nilai keakuratan Pakar 2 sebesar $\frac{27}{30} \times 100=90.00 \%$.

Hasil diagnosis Pakar Tiga dengan hasil diagnosis sistem, terdapat 26 hasil yang sesuai dan 4 hasil yang tidak sesuai yaitu pada pengujian kasus ke-3, ke-10 ke13, dan ke-28. Maka diperoleh nilai keakuratan Pakar 3 sebesar $\frac{26}{30} \times 100=86,67 \%$.

Setelah mendapatkan hasil kesesuaian hasil diagnosis ketiga Pakar dengan hasil diagnosis sistem. Selanjutnya menghitung nilai rata-rata persentase akurasi ketiga Pakar berdasarkan nilai akhir kepercayaan Pakar.

Rata-rata akurasi sistem $=\frac{93,33+90 \%+86,67 \%}{3}=90 \%$

\subsubsection{Akurasi berdasarkan Nilai Kepercayaan masing-masing Pakar}

tabel VI. Pengujian AkURasi Pakar 1

\begin{tabular}{|c|c|c|c|}
\hline $\begin{array}{c}\text { Kasus } \\
\text { ke- }\end{array}$ & $\begin{array}{c}\text { Hasil diagnosis } \\
\text { Pakar 1 }\end{array}$ & Hasil Diagnosis sistem & Keterangan \\
\hline 1 & $\begin{array}{c}\text { Busuk Buah } \\
\text { Antraknosa }\end{array}$ & $\begin{array}{c}\text { Busuk Buah } \\
\text { Antraknosa 99,94\% }\end{array}$ & Valid \\
\hline 2 & $\begin{array}{c}\text { Busuk Buah } \\
\text { Antraknosa }\end{array}$ & $\begin{array}{c}\text { Busuk Buah } \\
\text { Antraknosa 95,95\% }\end{array}$ & Valid \\
\hline
\end{tabular}




\begin{tabular}{|c|c|c|c|}
\hline 3 & $\begin{array}{l}\text { Layu Layu } \\
\text { Fusarium }\end{array}$ & Layu Fusarium 76,52\% & Valid \\
\hline 4 & Embun Tepung & $\begin{array}{c}\text { Embun Tepung, } 62.5 \\
\%\end{array}$ & Valid \\
\hline 5 & $\begin{array}{l}\text { Bercak Daun } \\
\text { Serkospora }\end{array}$ & $\begin{array}{c}\text { Bercak Daun } \\
\text { Serkospora } 87,69 \%\end{array}$ & Valid \\
\hline 6 & $\begin{array}{l}\text { Bercak Daun } \\
\text { Serkospora }\end{array}$ & $\begin{array}{c}\text { Bercak Daun } \\
\text { Serkospora } 86.12 \%\end{array}$ & Valid \\
\hline 7 & Virus Kuning & Virus Kuning 99,95\% & Valid \\
\hline 8 & Layu Bakteri & Layu Bakteri 92,15\% & Valid \\
\hline 9 & Embun Tepung & Layu Fusarium 80,13 & Tidak Valid \\
\hline 10 & Layu Fusarium & $\begin{array}{c}\text { Layu Fusarium } 80.35 \\
\% \%\end{array}$ & Valid \\
\hline 11 & $\begin{array}{l}\text { Busuk Buah } \\
\text { Antraknosa }\end{array}$ & $\begin{array}{c}\text { Busuk Buah } \\
\text { Antraknosa } 99,95 \%\end{array}$ & Valid \\
\hline 12 & Layu Bakteri & Layu Bakteri 88,75\% & Valid \\
\hline 13 & $\begin{array}{l}\text { Busuk Daun } \\
\text { Fitophora }\end{array}$ & $\begin{array}{c}\text { Busuk Daun Fitophora } \\
52.92 \%\end{array}$ & Valid \\
\hline 14 & $\begin{array}{l}\text { Busuk Daun } \\
\text { Fitophora }\end{array}$ & $\begin{array}{c}\text { Busuk Daun Fitophora } \\
94,66 \%\end{array}$ & Valid \\
\hline 15 & Embun Tepung & $\begin{array}{c}\text { Embun Tepung } \\
61,29 \%\end{array}$ & Valid \\
\hline 16 & $\begin{array}{l}\text { Bercak Daun } \\
\text { Serkospora }\end{array}$ & $\begin{array}{c}\text { Bercak Daun } \\
\text { Serkospora } 94,9 \%\end{array}$ & Valid \\
\hline 17 & Virus Kuning & Virus Kuning $98.34 \%$ & Valid \\
\hline 18 & $\begin{array}{l}\text { Busuk Daun } \\
\text { Fitophora }\end{array}$ & $\begin{array}{c}\text { Busuk Daun Fitophora } \\
93 \%\end{array}$ & Valid \\
\hline 19 & $\begin{array}{l}\text { Busuk Buah } \\
\text { Antraknosa }\end{array}$ & $\begin{array}{c}\text { Busuk Buah } \\
\text { Antraknosa } 99,75 \%\end{array}$ & Valid \\
\hline 20 & Layu Fusarium & Layu Fusarium 99,66\% & Valid \\
\hline 21 & Layu Bakteri & Layu Bakteri 95.37\% & Valid \\
\hline 22 & $\begin{array}{l}\text { Busuk Daun } \\
\text { Fitophora }\end{array}$ & $\begin{array}{c}\text { Busuk Daun Fitophora } \\
66,16 \%\end{array}$ & Valid \\
\hline 23 & Virus Kuning & Virus Kuning $99.96 \%$ & Valid \\
\hline 24 & Layu Bakteri & Layu Bakteri $94.38 \%$ & Valid \\
\hline 25 & $\begin{array}{l}\text { Bercak Daun } \\
\text { Serkospora }\end{array}$ & $\begin{array}{c}\text { Bercak Daun } \\
\text { Serkospora } 81,09 \%\end{array}$ & Valid \\
\hline 26 & $\begin{array}{l}\text { Busuk Buah } \\
\text { Antraknosa }\end{array}$ & $\begin{array}{c}\text { Busuk Buah } \\
\text { Antraknosa } 99.96 \%\end{array}$ & Valid \\
\hline 27 & Layu Bakteri & Layu Bakteri $94.33 \%$ & Valid \\
\hline 28 & Layu Bakteri & Layu Bakteri 81,13\% & Valid \\
\hline 29 & $\begin{array}{l}\text { Bercak Daun } \\
\text { Serkospora }\end{array}$ & $\begin{array}{c}\text { Bercak Daun } \\
\text { Serkospora } 98,1 \%\end{array}$ & Valid \\
\hline 30 & Layu Fusarium & Layu Fusarium 85.25\% & Valid \\
\hline
\end{tabular}

Tabel VIII merupakan perbandingan antara hasil diagnosis Pakar Satu dengan hasil diagnosis sistem berdasarkan nilai belief dari Pakar 1, terdapat 29 hasil sesuai dan 1 hasil tidak sesuai yaitu pada kasus ke-9. Maka diperoleh nilai keakuratan Pakar Satu sebesar $\frac{29}{30} \times 100=96,67 \%$.

tabel VII. Pengujian Akurasi Pakar 2

\begin{tabular}{|c|c|c|c|}
\hline $\begin{array}{c}\text { Kasus } \\
\text { ke- }\end{array}$ & $\begin{array}{c}\text { Hasil diagnosis } \\
\text { Pakar 2 }\end{array}$ & Hasil Diagnosis siste, & Keterangan \\
\hline 1 & $\begin{array}{c}\text { Busuk Buah } \\
\text { Antraknosa }\end{array}$ & $\begin{array}{c}\text { Busuk Buah } \\
\text { Antraknosa 100\% }\end{array}$ & Valid \\
\hline 2 & $\begin{array}{c}\text { Busuk Buah } \\
\text { Antraknosa }\end{array}$ & $\begin{array}{c}\text { Busuk Buah } \\
\text { Antraknosa 100\% }\end{array}$ & Valid \\
\hline 3 & Layu Fusarium & Layu Fusarium 100\% & Valid \\
\hline
\end{tabular}

\begin{tabular}{|c|c|c|c|}
\hline 4 & Embun Tepung & $\begin{array}{c}\text { Embun Tepung, } \\
97.75 \%\end{array}$ & Valid \\
\hline 5 & $\begin{array}{l}\text { Bercak Daun } \\
\text { Serkospora }\end{array}$ & $\begin{array}{c}\text { Bercak Daun } \\
\text { Serkospora } 100 \%\end{array}$ & Valid \\
\hline 6 & $\begin{array}{l}\text { Bercak Daun } \\
\text { Serkospora }\end{array}$ & $\begin{array}{c}\text { Bercak Daun } \\
\text { Serkospora } 100 \%\end{array}$ & Valid \\
\hline 7 & Virus Kuning & Virus Kuning $100 \%$ & Valid \\
\hline 8 & Layu Bakteri & Layu Bakteri $100 \%$ & Valid \\
\hline 9 & Embun Tepung & $\begin{array}{c}\text { Embun Tepung } \\
85.84 \% \\
\end{array}$ & Valid \\
\hline 10 & Layu Fusarium & Layu Fusarium $100 \%$ & Valid \\
\hline 11 & $\begin{array}{l}\text { Busuk Buah } \\
\text { Antraknosa }\end{array}$ & $\begin{array}{c}\text { Busuk Buah } \\
\text { Antraknosa } 100 \%\end{array}$ & Valid \\
\hline 12 & Layu Fusarium & Layu Bakteri $100 \%$ & Tidak Valid \\
\hline 13 & $\begin{array}{l}\text { Bercak Daun } \\
\text { Serkospora }\end{array}$ & $\begin{array}{c}\text { Bercak Daun } \\
\text { Serkospora } 100 \%\end{array}$ & Valid \\
\hline 14 & $\begin{array}{l}\text { Busuk Daun } \\
\text { Fitophora }\end{array}$ & $\begin{array}{l}\text { Busuk Daun Fitophora } \\
99,83 \%\end{array}$ & Valid \\
\hline 15 & Embun Tepung & Embun Tepung, 95.6\% & Valid \\
\hline 16 & $\begin{array}{l}\text { Bercak Daun } \\
\text { Serkospora }\end{array}$ & $\begin{array}{c}\text { Bercak Daun } \\
\text { Serkospora } 100 \% \\
\end{array}$ & Valid \\
\hline 17 & Virus Kuning & Virus Kuning $100 \%$ & Valid \\
\hline 18 & $\begin{array}{l}\text { Busuk Daun } \\
\text { Fitophora }\end{array}$ & $\begin{array}{c}\text { Busuk Daun Fitophora } \\
98,88 \%\end{array}$ & Valid \\
\hline 19 & $\begin{array}{l}\text { Busuk Buah } \\
\text { Antraknosa }\end{array}$ & $\begin{array}{c}\text { Busuk Buah } \\
\text { Antraknosa } 100 \%\end{array}$ & Valid \\
\hline 20 & Layu Fusarium & Layu Fusarium 100\% & Valid \\
\hline 21 & Layu Bakteri & Layu Bakteri 100\% & Valid \\
\hline 22 & $\begin{array}{l}\text { Bercak Daun } \\
\text { Serkospora }\end{array}$ & $\begin{array}{c}\text { Bercak Daun } \\
\text { Serkospora } 100 \%\end{array}$ & Valid \\
\hline 23 & Virus Kuning & Virus Kuning $100 \%$ & Valid \\
\hline 24 & Layu Bakteri & Layu Bakteri $100 \%$ & Valid \\
\hline 25 & $\begin{array}{l}\text { Bercak Daun } \\
\text { Serkospora }\end{array}$ & $\begin{array}{c}\text { Bercak Daun } \\
\text { Serkospora } 100 \%\end{array}$ & Valid \\
\hline 26 & $\begin{array}{l}\text { Busuk Buah } \\
\text { Antraknosa }\end{array}$ & $\begin{array}{c}\text { Busuk Buah } \\
\text { Antraknosa } 100 \% \\
\end{array}$ & Valid \\
\hline 27 & Layu Bakteri & Layu Bakteri $100 \%$ & Valid \\
\hline 28 & Layu Bakteri & Layu Bakteri $100 \%$ & Valid \\
\hline 29 & $\begin{array}{c}\text { Bercak Daun } \\
\text { Serkospora }\end{array}$ & $\begin{array}{c}\text { Bercak Daun } \\
\text { Serkospora } 100 \%\end{array}$ & Valid \\
\hline 30 & Layu Fusarium & Fusarium $100 \%$ & Valid \\
\hline
\end{tabular}

Tabel VII dmerupakan perbandingan antara hasil diagnosis Pakar Dua dengan hasil diagnosis sistem berdasarkan nilai belief dari Pakar Dua, terdapat 29 hasil yang sesuai dan satu hasil yang tidak sesuai yaitu pada pengujian kasus ke-12. Maka diperoleh nilai keakuratan Pakar Dua sebesar $\frac{29}{30} \times 100=96,67 \%$.

TABEL VIII. PENGUJIAN AKURASI PAKAR 3

\begin{tabular}{|c|c|c|c|}
\hline $\begin{array}{c}\text { Kasus } \\
\text { ke- }\end{array}$ & $\begin{array}{c}\text { Hasil diagnosis } \\
\text { Pakar 2 }\end{array}$ & Hasil Diagnosis siste, & Keterangan \\
\hline 1 & $\begin{array}{c}\text { Busuk Buah } \\
\text { Antraknosa }\end{array}$ & $\begin{array}{c}\text { Busuk Buah } \\
\text { Antraknosa 99,89\% }\end{array}$ & Valid \\
\hline 2 & $\begin{array}{c}\text { Busuk Buah } \\
\text { Antraknosa }\end{array}$ & $\begin{array}{c}\text { Busuk Buah } \\
\text { Antraknosa 99.95\% }\end{array}$ & Valid \\
\hline 3 & Layu Bakteri & $\begin{array}{c}\text { Layu Bakteri 76.52\% } \\
\text { Vaym }\end{array}$ & Valid \\
\hline 4 & Embun Tepung & $\begin{array}{c}\text { Embun Tepung, 97.75 } \\
\text { Valid }\end{array}$ & \\
\hline
\end{tabular}




\begin{tabular}{|c|c|c|c|}
\hline 5 & $\begin{array}{l}\text { Bercak Daun } \\
\text { Serkospora }\end{array}$ & $\begin{array}{c}\text { Bercak Daun } \\
\text { Serkospora } 92.58 \%\end{array}$ & Valid \\
\hline 6 & $\begin{array}{l}\text { Bercak Daun } \\
\text { Serkospora }\end{array}$ & $\begin{array}{c}\text { Bercak Daun } \\
\text { Serkospora } 93.54 \%\end{array}$ & Valid \\
\hline 7 & Virus Kuning & Virus Kuning $98.13 \%$ & Valid \\
\hline 8 & Layu Bakteri & Layu Bakteri 97.05\% & Valid \\
\hline 9 & Embun Tepung & Embun Tepung $92.3 \%$ & Valid \\
\hline 10 & Layu Bakteri & Layu Fusarium 70.83\% & Tidak Valid \\
\hline 11 & $\begin{array}{l}\text { Busuk Buah } \\
\text { Antraknosa }\end{array}$ & $\begin{array}{c}\text { Busuk Buah } \\
\text { Antraknosa 99,95\% }\end{array}$ & Valid \\
\hline 12 & Layu Bakteri & Layu Bakteri 97.52\% & Valid \\
\hline 13 & $\begin{array}{l}\text { Busuk Daun } \\
\text { Fitophora }\end{array}$ & $\begin{array}{c}\text { Busuk Daun Fitophora } \\
58,12 \%\end{array}$ & Valid \\
\hline 14 & $\begin{array}{l}\text { Busuk Daun } \\
\text { Fitophora }\end{array}$ & $\begin{array}{c}\text { Busuk Daun Fitophora } \\
99.44 \%\end{array}$ & Valid \\
\hline 15 & Embun Tepung & $\begin{array}{c}\text { Embun Tepung, } \\
97.02 \%\end{array}$ & Valid \\
\hline 16 & $\begin{array}{c}\text { Bercak Daun } \\
\text { Serkospora }\end{array}$ & $\begin{array}{c}\text { Bercak Daun } \\
\text { Serkospora } 93,27 \%\end{array}$ & Valid \\
\hline 17 & Virus Kuning & Virus Kuning $100 \%$ & Valid \\
\hline 18 & $\begin{array}{l}\text { Busuk Daun } \\
\text { Fitophora }\end{array}$ & $\begin{array}{c}\text { Busuk Daun Fitophora } \\
98.88 \%\end{array}$ & Valid \\
\hline 19 & $\begin{array}{l}\text { Busuk Buah } \\
\text { Antraknosa }\end{array}$ & $\begin{array}{c}\text { Busuk Buah } \\
\text { Antraknosa 99,83\% }\end{array}$ & Valid \\
\hline 20 & Layu Fusarium & Layu Fusarium $96.25 \%$ & Valid \\
\hline 21 & Layu Bakteri & Layu Bakteri 98.79\% & Valid \\
\hline 22 & $\begin{array}{l}\text { Busuk Daun } \\
\text { Fitophfora }\end{array}$ & $\begin{array}{l}\text { Busuk Daun Fitophora } \\
92.95 \%\end{array}$ & Valid \\
\hline 23 & Virus Kuning & Virus Kuning $100 \%$ & Valid \\
\hline 24 & Layu Bakteri & Layu Bakteri 98,88\% & Valid \\
\hline 25 & $\begin{array}{c}\text { Busuk Daun } \\
\text { Fitophora }\end{array}$ & $\begin{array}{c}\text { Busuk Daun Fitophora } \\
58.12 \% \\
\end{array}$ & Valid \\
\hline 26 & $\begin{array}{l}\text { Busuk Buah } \\
\text { Antraknosa }\end{array}$ & $\begin{array}{c}\text { Busuk Buah } \\
\text { Antraknosa } 99,97 \% \\
\end{array}$ & Valid \\
\hline 27 & Layu Bakteri & Layu Bakteri $98,76 \%$ & Valid \\
\hline 28 & $\begin{array}{l}\text { Busuk Daun } \\
\text { Fitophora }\end{array}$ & $\begin{array}{c}\text { Busuk Daun Fitophora } \\
62 . .67 \%\end{array}$ & Valid \\
\hline 29 & $\begin{array}{l}\text { Bercak Daun } \\
\text { Serkospora }\end{array}$ & $\begin{array}{c}\text { Bercak Daun } \\
\text { Serkospora } 98.52 \% \\
\end{array}$ & Valid \\
\hline 30 & Layu Fusarium & Virus Kuning 49,66\% & Tidak Valid \\
\hline
\end{tabular}

Tabel $X$ merupakan perbandingan antara hasil diagnosis Pakar Tiga dengan hasil diagnosis sistem berdasarkan nilai belief dari Pakar Tiga, terdapat 28 hasil yang sesuai dan 2 hasil yang tidak sesuai yaitu pada pengujian kasus ke-10 dan ke-30. Maka diperoleh nilai keakuratan Pakar Tiga sebesar $\frac{28}{30} \times 100=$ 93,33\%.

Pengujian akurasi sistem berdasarkan nilai kepercayaan masing masing pakar diperoleh akurasi sebesar 96,67\% untuk Pakar Sau, 96,67\% untuk Pakar Dua dan 93,33\% untuk Pakar Tiga. Adanya perbedaan pengetahuan pakar menyebabkan terdapat beberapa hasil diagnosis yang diberikan setiap pakar berbeda.

Berdasarkan pengujian yang telah dilakukan, diperolah rata-rata akurasi berdasarkan nilai akhir kepercayaan tiga pakar sebesar $90 \%$ dan nilai akurasi berdasarkan nilai kepercayaan masing-masing pakar yaitu sebesar 96,67\% untuk Pakar Satu, 96,67\% untuk Pakar Dua dan 93,33\% untuk Pakar Tiga. Hasil pengujian tersebut menunjukan bahwa akurasi berdasarkan nilai akhir kepercayaan tiga pakar cendrung lebih rendah dibandingkan dengan akurasi masing-masing pakar. Hal tersebut dikarenakan nilai kepercayaan yang digunakan pada pengujian sekenario pertama adalah nilai rata-rata kepercayaan tiga pakar sedangkan nilai kepercayaan yang digunakan pada pengujian sekenario kedua adalah nilai kepercayaan pakar itu sendiri serta perbedaan pengetahuan dan pengalaman pakar mempengaruhi hasil diagnosis setiap pakar.

\subsection{Pengujian Mean Opinion Score (MOS)}

Pengujian MOS dilakukan kepada 25 orang responden yang dibagi menjadi empat kategori yaitu mahasiswa teknik informatika untuk menguji interface dan user friendly sistem, mahasiswa pertanian untuk menguji informasi yang ditampilkan sistem sesuai dengan ilmu yang didapatkan di bangku perkuliahan, penyuluh pertanian untuk menguji dari kemudahan sistem dan apakah informasi yang diberikan sistem sesuai dengan yang diharapkan, dan petani untuk menguji apakah sistem dapat memberikan yang dibutuhkan.

Pengujian MOS untuk mahasiswa teknik informatika dengan kuesioner sebagai berikut.

Pertanyaan 1: Tampilan sistem pakar penyakit cabai ini menarik.

Pertanyaan 2: $\quad$ Sistem pakar diagnosis penyakit pada tanaman cabai ini mudah digunakan (user fiendly).

Pertanyaan 3: Penggunaan warna, tampilan, da jenis huruf pada sistem pakar ini sudah sesuai.

Pertanyaan 4: Fitur-fitur yang ada pada sistem pakar diagnosis penyakit pada tanaman cabai bekerja dengan baik

Pertanyaan 5: Anda akan menggunakan sistem pakar ini untuk membantu diagnosis penyakit pada tanaman cabai anda pada waktu yang akan datang.

TABEL IX. HASIL PENGUJIAN MOS MahASISWA TEKNIK INFORMATIKA

\begin{tabular}{|c|c|c|c|c|c|c|c|c|}
\hline No & Pertanyaan & $\begin{array}{l}\text { SS } \\
\text { (5) }\end{array}$ & $\begin{array}{c}S \\
\text { (4) }\end{array}$ & $\begin{array}{l}\text { TT } \\
\text { (3) }\end{array}$ & $\begin{array}{l}\text { TS } \\
\text { (2) }\end{array}$ & $\begin{array}{l}\text { STS } \\
(1)\end{array}$ & Total & $\begin{array}{c}\text { Mean } \\
\text { pi }\end{array}$ \\
\hline 1 & Pertanyaan 1 & 3 & 2 & - & - & - & 5 & 4,6 \\
\hline 2 & Pertanyaan 2 & 3 & 2 & - & - & - & 5 & 4,6 \\
\hline 3 & Pertanyaan 3 & 1 & 4 & - & - & - & 5 & 4,2 \\
\hline 4 & Pertanyaan 4 & 3 & 1 & 1 & - & - & 5 & 4 \\
\hline 5 & Pertanyaan 5 & 1 & 4 & - & - & - & 5 & 4,2 \\
\hline \multicolumn{2}{|r|}{ Sub Total } & 11 & 13 & 1 & - & - & 25 & 21,6 \\
\hline & & & & & & & MOS & 4,35 \\
\hline
\end{tabular}

Berdasarkan hasil pengujian MOS pada Tabel XI yang telah dilakukan oleh lima mahasiswa Teknik 
Informatika diperoleh hasil perhitungan MOS sebesar 4,35 dari skala 5. Hasil tersebut menunjukkan dari segi interface dan user friendly sistem pakar diagnosis penyakit tanaman cabai yang dibangun sudah baik, tampilan menarik, mudah digunakan, penggunaan warna dan tampilan sistem sudah sesuai, membantu dalam mendiagnosis penyakit tanaman cabai dan dan dikemudian hari sistem bisa jadi terus digunakan dalam mendiagnosis tanaman cabai oleh masyarakat yang memiliki tanaman cabai khususnya petani cabai

Selanjutnya pengujian MOS untuk mahasiswa pertanian dengan kuesioner sebagai berikut.

Pertanyaan 1: Informasi yang ditampilkan sesuai atau tidak bertentangan dengan apa yang dipelajari di bangku perkuliahan.

Pertanyaan 2: $\quad$ Sistem pakar diagnosis penyakit tanaman cabai mampu memberikan hasil diagnosis yang sesuai.

Pertanyaan 3: Dengan adanya sistem pakar ini dapat memberikan informasi penanganan penyakit tanaman cabai.

Pertanyaan 4: Pemilihan gambar pendukung sesuai dengan informasi yang ditampilkan

Pertanyaan 5: Anda akan menggunakan sistem pakar ini untuk membantu diagnosis penyakit pada tanaman cabai anda pada waktu yang akan datang.

TABEL $X . \quad$ HASIL PENGUJIAN MOS MahasisWA Pertanian

\begin{tabular}{|c|c|c|c|c|c|c|c|c|}
\hline No & Pertanyaan & \begin{tabular}{|l|} 
SS \\
(5)
\end{tabular} & $\begin{array}{c}S \\
\text { (4) }\end{array}$ & $\begin{array}{l}T T \\
(3)\end{array}$ & $\begin{array}{l}\text { TS } \\
\text { (2) }\end{array}$ & $\begin{array}{l}\text { STS } \\
(1)\end{array}$ & Total & $\begin{array}{c}\text { Mean } \\
\text { pi }\end{array}$ \\
\hline 1 & Pertanyaan 1 & - & 5 & - & - & - & 5 & 4 \\
\hline 2 & Pertanyaan 2 & - & 3 & 1 & 1 & - & 5 & 3,4 \\
\hline 3 & Pertanyaan 3 & 1 & 4 & - & - & - & 5 & 4,2 \\
\hline 4 & Pertanyaan 4 & 3 & 2 & - & - & - & 5 & 4,6 \\
\hline 5 & Pertanyaan 5 & 1 & 2 & 2 & - & - & 5 & 3,8 \\
\hline \multicolumn{2}{|c|}{ Sub Total } & 5 & 16 & 3 & 1 & - & 25 & 20 \\
\hline & & & & & & & MOS & 4,0 \\
\hline
\end{tabular}

Berdasarkan hasil pengujian MOS pada Tabel XII yang telah dilakukan oleh lima mahasiswa Pertanian didapatkan hasil perhitungan MOS sebesar 4,0 dari skala 5. Hasil tersebut menunjukan bahwa dari sisi informasi yang diberikan sistem pakar diagnosis penyakit tanaman yang dibangun sesuai dengan yang telah dipelajari mahasiswa, membantu dalam mendiagnosis penyakit tanaman cabai dan dan dikemudian hari sistem bisa jadi terus digunakan dalam mendiagnosis tanaman cabai oleh masyarakat yang memiliki tanaman cabai khususnya petani cabai.

Selanjutnya pengujian MOS untuk penyuluh pertanian dengan kuesioner sebagai berikut.
Pertanyaan

1:

Pertanyaan

2:

Pertanyaan

3:

Pertanyaan

4:

Pertanyaan

5:

tABEL XI. Hasil PengujIan MOS Penyuluh PERTANIAN

\begin{tabular}{|c|c|c|c|c|c|c|c|c|}
\hline No & Pertanyaan & $\begin{array}{l}\text { SS } \\
\text { (5) }\end{array}$ & $\begin{array}{c}S \\
\text { (4) }\end{array}$ & $\begin{array}{l}T T \\
(3)\end{array}$ & $\begin{array}{l}\text { TS } \\
\text { (2) }\end{array}$ & $\begin{array}{l}\text { STS } \\
\text { (1) }\end{array}$ & Total & $\begin{array}{c}\text { Mean } \\
\text { pi }\end{array}$ \\
\hline 1 & Pertanyaan 1 & 2 & 3 & - & - & - & 5 & 4,4 \\
\hline 2 & Pertanyaan 2 & 4 & 1 & - & - & - & 5 & 4,8 \\
\hline 3 & Pertanyaan 3 & 3 & 2 & - & - & - & 5 & 4,6 \\
\hline 4 & Pertanyaan 4 & 4 & 1 & - & - & - & 5 & 4,8 \\
\hline 5 & Pertanyaan 5 & 4 & 1 & - & - & - & 5 & 4,8 \\
\hline \multirow{2}{*}{\multicolumn{8}{|c|}{ Sub Total }} & 23,4 \\
\hline & & & & & & & & 4,68 \\
\hline
\end{tabular}

Berdasarkan hasil pengujian MOS pada Tabel XIII yang telah dilakukan oleh lima Penyuluh Pertanian diperoleh hasil perhitungan MOS sebesar 4,68 dari skala 5. Hasil tersebut menunjukan bahwa dari sisi informasi yang ditampilkan sistem pakar yang dibangun dapat menampilkan informasi mengenai penyakit tanaman cabai, memudahkan dalam mendiagnosis penyakit, memberikan akurasi yang sesuai, membantu dalam mendiagnosis penyakit tanaman cabai dan dikemudian hari sistem bisa jadi terus digunakan dalam mendiagnosis tanaman cabai oleh masyarakat yang memiliki tanaman cabai khususnya petani cabai

Selanjutnya pengujian MOS untuk petani dengan kuesioner sebagai berikut

Pertanyaan 1: $\quad$ Sistem pakar penyakit tanaman cabai ini mudah digunakan

Pertanyaan 2: Adanya sistem pakar ini dapat membantu untuk mendiagnosis penyakit pada tanaman cabai menjadi lebih mudah

Pertanyaan 3: Adanya sistem pakar ini dapat memberikan informasi tentang penyakit pada tanaman cabai

Pertanyaan 4: Informasii yang diberikan oleh sistem pakar diagnosis penyakit pada 
tanaman cabai ini sudah sesuai dengan kebutuhan.

Pertanyaan 5: Anda akan menggunakan sistem pakar ini untuk membantu diagnosis penyakit pada tanaman cabai anda pada waktu yang akan datang.

TABEL XII. HASIL PENGUJIAN MOS PETANI

\begin{tabular}{|c|c|c|c|c|c|c|c|c|}
\hline No & Pertanyaan & $\begin{array}{l}\text { SS } \\
\text { (5) }\end{array}$ & $\begin{array}{c}S \\
\text { (4) }\end{array}$ & \begin{tabular}{|l|}
$T T$ \\
(3)
\end{tabular} & $\begin{array}{l}\text { TS } \\
\text { (2) }\end{array}$ & $\begin{array}{l}\text { STS } \\
(1)\end{array}$ & Total & $\begin{array}{c}\text { Mean } \\
p i\end{array}$ \\
\hline 1 & Pertanyaan 1 & 4 & 6 & - & - & - & 10 & 4,4 \\
\hline 2 & Pertanyaan 2 & 6 & 4 & - & - & - & 10 & 4,6 \\
\hline 3 & Pertanyaan 3 & 7 & 3 & - & - & - & 10 & 4,7 \\
\hline 4 & Pertanyaan 4 & 3 & 6 & 1 & - & - & 10 & 4,2 \\
\hline 5 & Pertanyaan 5 & 8 & 2 & - & - & - & 10 & 4,8 \\
\hline \multicolumn{2}{|c|}{ Sub Total } & 28 & 21 & 1 & - & - & 50 & 22,7 \\
\hline & & & & & & & MOS & 4,54 \\
\hline
\end{tabular}

Berdasarkan hasil pengujian MOS pada Tabel XIV yang telah dilakukan oleh 10 petani diperoleh hasil perhitungan MOS sebesar 4,54 dari skala 5. Hasil tersebut menunjukan bahwa dari sisi informasi yang diberikan sistem yang dibangun mudah digunakan, dapat lebih mudah mendiagnosis tanaman cabai, informasi sesuai kebutuhan, membantu dalam mendiagnosis penyakit tanaman cabai dan dikemudian hari sistem bisa jadi terus digunakan dalam mendiagnosis tanaman cabai oleh masyarakat yang memiliki tanaman cabai khususnya petani cabai.

Berdasarkan hasil pengujian MOS yang telah dilakukan pada Tabel XI, Tabel XII, Tabel XII dan Tabel XIV yaitu 4.35, 4.0, 4.68 dan 4.54 dari skala 5. Sehingga dapat disimpulkan hasil tersebut menunjukan bahwa kualitas sistem pakar yang dibangun dikategorikan sistem good (baik).

\section{KeSIMPULAN DAN SARAN}

\subsection{Kesimpulan}

Berdasarkan hasil analisa dan pengujian pada sistem pakar untuk mendiagnosis penyakit tanaman cabai menggunakan metode Forward Chaining dan Dempster Shafer, diperoleh kesimpulan sebagai berikut:

a. Sistem pakar yang dibangun mampu mengidentifikasikan 7 penyakit tanaman cabai berdasarkan pengetahuan 3 pakar dan hasil perhitungan sesuai dengan hasil perhitungan manual.

b. Berdasarkan pengujian akurasi sistem diperoleh nilai akhir tingkat akurasi sebesar 90,00\%, 96,67\% untuk akurasi Pakar Satu, 96,67\% untuk akurasi Pakar Dua dan 93,33\% untuk akurasi Pakar Tiga pada 30 kasus yang diujikan. c. Sistem pakar memiliki nilai MOS sebesar 4,35 untuk mahasiswa Teknik Informatika, 4 untuk mahasiswa Pertanian, 4,68 untuk Penyuluh Pertanian dan 4,54 untuk petani yang menunjukan sistem layak digunakan dan dikategorikan ke dalam sistem yang baik.

\subsection{Saran}

Saran yang dapat diberikan dalam pengembangan sistem ini agar menjadi lebih baik adalah sebagai berikut:

a. Diharapkan sistem yang telah dibangun dapat dikembangkan menjadi sistem pakar berbasis mobile dengan arsitektur client - server agar lebih mudah digunakan melalui smartphone.

b. Sistem pakar diagnosis tanaman cabai ini dapat juga dikembangkan dengan metode perhitungan yang lain seperti metode certainty factor maupun bayes. Sehingga dapat dilakukan perbandingan metode mana yang lebih tepat dalam mendiagnosis penyakit tanaman cabai.

c. Diharapkan pada pengembangan selanjutnya terkait penelitian ini, kasus uji pada pengujian akurasi diperoleh dari masing-masing pakar.

\section{DAFTAR PUSTAKA}

[1] E. Elvinardewi and A. Hikmat, Pengendalan dan Pengendalian Organisme Pengganggu Tumbuhan (OPT) Cabai. Jakarta: Direktorat Bina Perlindungan Tanaman, 1999.

[2] "Statistik Tanaman Sayuran dan Buah-buahan Semusim Indonesia 2018." Badan Pusat Statistik Indonesia, Jakarta, 2019.

[3] M. Indriyana, Statistik Produksi Tanaman Hortikultura Provinsi Nusa Tenggara Barat 2018. Mataram: Badan Pusat Statistik Provinsi Nusa Tenggara Barat Dilarang, 2019.

[4] A. S. Duriat and N. Gunaeni, Penyakit Penting Tanaman Cabai dan Pengendalinya. Bandung: Balai Penelitian Tanaman Sayuran, 2007.

[5] R. Rusmi, Defiaryani, and S. Purwanti, "Webbases Expert System For Diagnosing Pest and Disease In Chili Plant Using Forward Chaining," JSI, vol. 2, no. 2, pp. 61-75, 2016.

[6] K. Aryasa, "Sistem Pakar Diagnosa Penyakit Tanaman Agribisnis Menggunakan Metode Certainty Factor," J-siti, vol. 7, no. 1, pp. 54-67, 2018.

[7] W. Verina, "Penerapan Metode Forward Chaining untuk Mendeteksi Penyakit THT," Jatisi, vol. 1, no. 2, pp. 123-138, 2015.

[8] D. Hastari and F. Bimantoro, "Sistem Pakar untuk Mendiagnosis Gangguan Mental Anak 
Menggunakan Metode Dempster Shafer," JCOSINE, vol. 2, no. 2, pp. 71-79, 2018.

[9] D. T. Yuwono and A. Fadlil, "Comparative Analysis of Dempster-Shafer Method and Certainty Factor Method On Personality Disorders Expert Systems," SJI, vol. 6, no. 1, pp. 12-22, 2019.

[10] F. Agus, H. E. Wulandari, and I. F. Astut, "Expert System With Certainty Factor For Early Diagnosis Of Red Chili Peppers Diseases," JAIS, vol. 2, no. 2, pp. 52-66, 2017.

[11] Y. A. Fitrianingtyas and C. Rahmad, "Sistem Pakar Deteksi Hama Dan Penyakit Pada Tanaman Cabai Dengan Metode Naïve Bayes," J. Polinema, vol. 2015, pp. 68-72, 2015.

[12] A. Mahmudi, M. Rokhman, and A. E. Prasetyo, "Rancang Bangun Sistem Pakar Untuk Mendiagnosis Tanaman Cabai Menggunakan Metode Bayes," 2016, vol. 2, no. 2, pp. 85-90, 2016.

[13] W. Supartini and Hindarto, "Sistem Pakar Berbasis Web Dengan Metode Forward Chaining Dalam Mendiagnosis Dini Penyakit Tuberkulosis di JawaTimur," KINETIK, vol. 1, no. 3, pp. 147-154, 2016.

[14] K. Bhaskara, N. Hidayat, and L. Muflikhah, "Sistem Diagnosis Penyakit Kelamin Pada Pria Menggunakan Metode Forward Chaining Dan Dempster-Shafer," J-ptiik, vol. 3, no. 3, pp. 28232828, 2019.

[15] M. Z. Muttaqin, E. Santoso, and B. Rahayudi, "Sistem Diagnosis Penyakit Ikan Koi Menggunakan Metode Forward Chaining dan Dempster-Shafer," J-ptiik, vol. 2, no. 8, pp. 28862891, 2018.

[16] S. Orthega, N. Hidayat, and E. Santoso,
"Implementasi Metode Dempster-Shafer untuk Mendiagnosa Penyakit Tanaman Padi," vol. 1, no. 10, 2017.

[17] R. A. Wicaksono, N. Hidayat, and Indriati, "Implementasi Metode Dempster-Shafer untuk Diagnosis Penyakit pada Tanaman Kedelai," Jptiik, vol. 2, no. 3, pp. 1212-1218, 2018.

[18] J. R. Maulana, Fitriyadi, and R. Fitriani, "Sistem Pakar Diagnosis Penyakit Tanaman Karet Dengan Metode Dempster-shafer," JUTISI, vol. 5, no. 5, pp. 1013-1021, 2017.

[19] M. Handayani, Taufiq, and Soegiarto, "Sistem Pakar Diagnosa Penyakit Tanaman Semangka Menggunakan Metode Dempster Shafer Berbasis Web," Progresif, vol. 12, no. 1, pp. 1243-1386, 2016.

[20] D. Purnomo, B. Irawan, and Y. Brianorman, "Sistem Pakar Diagnosa Penyakit Pada Kucing Menggunakan Metode Dempster-Shafer Berbasis Android," JCSKO, vol. 05, no. 1, pp. 45-55, 2017.

[21] R. Hamidi, H. Anra, and H. S. Pratiwi, "Analisis Perbandingan Sistem Pakar dengan Metode Certainty Factor dan Metode Dempster-Shafer pada Penyakit Kelinci," JUSTIN, vol. 5, no. 2, pp. 38, 2017.

[22] K. Adhianto, R. Andrian, and Y. N. Sari, "Comparative Analysis of Cow Disease Diagnosis Expert System using Bayesian Network and Dempster-Shafer Method," IJACSA, vol. 10, no. 4, pp. 227-235, 2019.

[23] K. Sentz and S. Ferson, Combination of Evidence in Dempster- Shafer Theory. New Mexico: Sandia National Laboratories, 2002. 